\title{
Effects of graded levels of boiled wild sunflower (Tithonia diversifolia Hemsl A. Gray) leaf meal on growth and carcass characteristics of rabbits.
}

Foku Vitalis Khan ${ }^{1}$, Defang Henry Fualefac ${ }^{1,2}$, Kana Serge Derrick Augustin ${ }^{1}$, Amandine Matho $^{1}$, Fonteh Florence Anyangwe Angaba ${ }^{1,3}$, Mube Kuiate Hervè ${ }^{1}$, Ndukum Julius Awah $^{1,3}$.

${ }^{1}$ Department of Animal Production, Faculty of Agronomy and Agricultural Sciences, University of Dschang,

Tel: +2372334513 81, udsrectorat@univ-dschang.org bttp:/ / wmw.univ-dschang.org/, P.O. Box 222, Dschang, Cameroon

${ }^{2}$ Faculty of Agriculture and Veterinary Medicines, Government Technical Teachers Training College, Kumba, University of Buea, info@,ubuea.cm, (+237) 233322760, P.O Box 249 Buea road, 237 Kumba, Cameroun;

${ }^{3}$ Faculty of Science, University of Bamenda, Bambili, NW Region, Cameroon. + (237) 233360033 OR + (237) 233

366 029, info@uniba-edu.cm + (237) 233366 030, P.O. Box 39, Bambili

khanvitalis@yahoo.co.uk,+237675464127;fdefang@yahoo.com,+237672919237;_Amandine matho@yahoo.com.

+237675226560; kanasagne@yahoo.ca,+237654801256; fontehflorence@yahoo.com,+237677577840;

mubehervemkh@yahoo.com.+237674596159; awabndukum@yahoo.com,237677236435

Correspondingauthor'semail: khanvitalis@yaboo.co.uk

Key words: T. diversifolia leaves, boiling, growth performance, carcass characteristics, rabbit.

Publication date 31/08/2019, http://www.m.elewa.org/JAPS

\section{RESUME}

To contribute solutions to the problem of animal protein shortage for human consumption in Cameroon, a study was conducted at the Teaching and Research Farm of the University of Dschang- Cameroon to evaluate the effects of inclusion levels of Tithonia diversifolia leaf meal (TDLM) on growth performance and carcass characteristics of rabbits. The leaves were chopped, boiled for 5 minutes, drained, sundried, milled and analysed for proximate composition in the Laboratory of Animal Nutrition. The leaf meal was used to formulate 4 experimental diets containing $0 \%$ (control) 15,20 and $25 \%$ of the TDLM, corresponding to T0, T1, T2 and T3, respectively. A total of 40 (20 males and 20 females) 2-months-old rabbits, weighing $1000 \pm 125 \mathrm{~g}$ were randomly assigned to the 4 dietary treatments in a $4 \times 10$ replicates in a completely randomized design. The live weights of the animals were evaluated weekly for 9 weeks. Eight (8) rabbits ( 4 males and 4 females) per treatment were randomly selected and sacrificed for carcass evaluation. The data collected were then submitted to one-way Analysis of Variance (ANOVA). Mean differences were separated using Duncan. The results showed that incorporation of TDLM induced a decrease in daily feed consumption. The least daily feed intake was observed in treatment T3 $(109.14 \mathrm{~g} / \mathrm{d})$ while the highest daily weight gain $(24.49 \mathrm{~g} / \mathrm{d})$ and the least feed conversion ratio (4.61) were also observed in the same treatment T3. However, no significant differences were observed for these parameters $(\mathrm{P}>0.05)$ between the treatments although daily weight gain was higher and feed conversion ratio lower in the males as compared to the females. Carcass yield (C.Y.) was higher in the control T1 $(52.39 \%)$ though comparable $(\mathrm{P}>0.05)$ with all the other treatments. Abdominal fat was significantly $(\mathrm{P}<0.05)$ lower $(1.90 \%)$ in the treatment T0 but it was comparable to T3 while it was highest $(2.28 \%)$ in T2. However, C.Y. was higher in males and abdominal fat was higher in females when sex was considered. The relative weight of the lungs was highest in T1 $(0.55 \%)$, liver in T2 $(2.25 \%)$, kidneys in T1 $(0.56 \%)$ and 
the heart in treatment T2 $(0.25 \%)$ though, there were no significant differences $(\mathrm{P}>0.05)$ observed in organs weights. Although there were significant differences between organs of different sexes, no regular pattern was maintained. These all signified nutritional adequacy at all levels of inclusion of TDLM, improving growth performance at the inclusion level of 25\%. T. diversifolia leaves boiled for 5 minutes, sundried and milled can therefore be used as an alternative ingredient which when included in the rations of rabbits up to $25 \%$, still compares well with conventional ingredients in growth and carcass performance irrespective of the sex. However, the use of TDLM could significantly reduce the cost of feeding and enhance meat production as it is relatively more abundant as compared to other ingredients.

\section{INTRODUCTION}

Agricultural production in Cameroon is estimated to grow at $2.2 \%$, lower than the annual demographic expansion rate of $2.9 \%$ (FAO, 2005). This disequilibrium shows a limitation in food supply and explains why food importation and particularly proteins of animal origin is inevitable in Cameroon (Awono et al., 2005). According to the norms laid down by the Food and Agricultural Organisation (FAO) and the World Health Organisation (WHO), the quantity of proteins of animal origin necessary for an individual is $42 \mathrm{~kg} /$ caput/year. Meanwhile, in Cameroon, the animal production sector is not capable of providing the population with $34 \mathrm{~kg} /$ caput of meat/year (Awono et al., 2005). The low level of production of proteins of animal origin is strongly linked to feeding cost which represents a very important potion of animal production. In fact, there is high competition between humans and domestic animals for cereals and legume grains and this tends to raise the cost of animal feed. As a consequence, nutrition research in livestock should focus on alternative sources of feeds to avoid direct competition for food between man animals. These includes agro-industrial by-products and forages, notably the leguminous and Asteracaea (composite or head family) families such as $T$. diversifolia species; an invading species which grows abundantly and uncultivated on road sides, infertile lands, fallow lands in the forest and tropical savannah (Akinola et al., 1999). In Cameroon, $T$. diversifolia is commonly called the wild sunflower, or fleure jalousie" (French appellation) due to the bright yellow colour (signifying jealousy) of its flowers and its ability to suppress and eliminate a wide variety of herbs and invade the area. It is drought resistant and the leaves are abundant and green throughout the year, yielding averagely $70-75$ Tones/ha/year (Ernest, 2002). Nutritional studies conducted on the leaves revealed that crude protein vary from $14-30 \%$, ashes $8-$ $20)$, crude fibre $(>10 \%)$ and lipids $(2-5 \%)$ (Mahecha and Rosales, 2005; Foku, 2014). The variation in nutrient composition depends on the state of maturity at which it was harvested, the ecological zone and the processing method (Wambui et al., 2006; Pathoummalangsy and Preston, 2008; Fasuyi et al., 2010). However, the presence of anti-nutrients in the leaves, notably: tannins $(0.39 \%)$, phytic acid $(79.1 \%)$, alkaloids $(1.23 \%)$, oxalate $(1.76 \%)$, flavonoids $(0.87 \%)$ and saponins $(2.36 \%)$ makes he leaves bitter and this contributes to the problem of acceptability among different species of animals (Fasuyi et al., 2010). However, simple processing techniques such as boiling can considerably reduce the level of anti-nutrients as well as enhance palatability and digestibility (Sallau et al., 2012). Boiling has been associated with significant reduction of cyanide in Moringa oleifera leaves by $88.10 \%$ (Sallau et al., 2012), reduction of oxalate content of Arachis bypogaea $L$ (Groundnut) from $3.04 \mathrm{mg} / \mathrm{g}$ to $2.62 \mathrm{mg} / \mathrm{g}$ and trypsin inhibitor from $0.12 \mathrm{TUI} / \mathrm{g}$ to 0.09 TUI/g. Nonetheless, excessive heating may negatively affect protein quality of food/feed (Mada et al., 2012). Another remedy to meet up 
with the required quantity of animal proteins will be to focus on the production of short cycle animals including birds, pigs and rabbits. However, domestic rabbits (Oryctolagus cuniculus) compared to other domestic animals are preferred because they are monogastric herbivores and do not compete directly with human beings for food. Also, rapid growth rate of up to $39.7 \mathrm{~g} /$ day have been observed in parts of the world (Ayers et al., 1996) and 14-20 $\mathrm{g} /$ day in Cameroon (Foku, 2014). They are fast maturing (4-5 months), attain market weight (2$2.5 \mathrm{Kg})$ at $10-12$ weeks. Moreover, rabbits can be raised on low grain diets high in roughage. They are well adapted to backyard production systems which do not require much capital and space. Furthermore, rabbits have high reproductive potential due to high prolificacy and a short gestation period ( $28-32$ days). A doe is capable of producing averagely 8

\section{MATERIALS AND METHODS}

3.1 Study zone: The study was carried out at the rabbit unit of the Teaching and Research Farm of the Faculty of Agronomy and Agricultural Sciences (FAAS), University of Dschang; located at $1420 \mathrm{~m}$ above sea level; between latitude $5^{\circ}-6^{\circ} \mathrm{N}$ and longitude $10^{\circ}-$ $11^{\circ} \mathrm{E}$ with an equato-guinean climate tempered by altitude. The annual temperature and relative humidity range between $10-25^{\circ} \mathrm{C}$ and 49 97\% respectively (Pamo et al., 2005). The area receives an annual rainfall between 1500 - 2000 $\mathrm{mm}$. The zone has a long wet season (mid March to mid-November) and short dry season (late November to early March).

3.2 Preparation of test ingredients : The wild sunflower ( $T$. diversifolia Hemsl A. Gray) leaves used for this experiment were harvested during late February and early March from the uncultivated plots of the University of Dschang Teaching and Research Farm, prior to the flowering stage $(7 \pm 1$ weeks old). The leaves were chopped $(2 \pm 1 \mathrm{~cm})$ with machetes and immersed in boiling water for 5 minutes, removed, drained, air-cold by spreading on a mat, sun-dried to a constant weight and milled using a harmer milled of sieve size $2 \mathrm{~mm}$ to kits/kindling and averagely 7 kindles/year, giving 56 kits/doe/year with mortality rate of $5 \%$. Rabbits have the ability to rebreed immediately after parturition (Effiong and Wogar, 2007). No other animal in livestock breeding has this amazing reproductive efficiency. Moreover, rabbit meat is a delicacy and of high quality with $20-22 \%$ proteins, low calories $(1749 \mathrm{kcal} \mathrm{kg})$ low fat content $(1-11 \%)$ and lowest cholesterol $(169 \mathrm{mg} / 100 \mathrm{~g})$ when compared with beef (200 mg/100g), chicken $(220 \mathrm{mg} / 100 \mathrm{~g})$ and pork (223 $\mathrm{mg} / 100 \mathrm{~g})$ (Janieri, 1997; Asit; 2014). In this context, this study was conducted to contribute to the knowledge of animal production with the use of alternative sources of feeds and more specifically, to evaluate the effect of inclusion of different levels of boiled $T$. diversifolia leaves on the growth performances and carcass characteristics of rabbit.

form a leaf meal. Samples of the meal were immediately taken and analysed for proximate composition in the laboratory of Animal Nutrition according to AOAC (1990). The rest of the leaf meal was stored in air-tied polythene bags prior to use in experimental diets.

3.3 Animals and prophylactics: Forty rabbits (20 males and 20 females) aged $7 \pm 1$ weeks were selected from among 180 rabbits in the Rabbit Unit of The Research and Teaching Farm of the University of Dschang. Prior to the commencement of the experiment, the rabbits were prophylactically treated against internal and external parasites with Ivermectine $\AA$ (subcutaneous) injection. A broad spectrum antibiotic (Oxyteracyline ${ }^{\circledR}$ L.A) was also administered alongside an anti-coccidioses (Vetacox $($ ) according to the manufacturer`s prescription. The entire rabbit unit, cages, drinking troughs and feeders were thoroughly washed with detergent and disinfected with $L a$ Croix. Two weeks prior to the commencement of the experiment, the floor and walls of the rabbit house were washed and disinfected with cresyl and $\mathrm{La}$ Croix in the ratio $20 \mathrm{ml}: 10$ lit $\mathrm{H}_{2} \mathrm{O}$ $+0.5 \mathrm{Kg}$ chaux (whitewash). 
3.4 Housing: The rabbits were housed individually in specially constructed metal cages (Californian type) measuring $45 \times 40 \times 15 \mathrm{~cm}$, inside a semi-closed rabbit unit $1.5 \mathrm{~m}$ high and the upper part $(1.2 \mathrm{~m})$ closer to the roof was completed with wire mesh for proper ventilation and dissipation of heat. Each cage was equipped with a feeder and a water trough. The building was roofed with aluminium sheets.

\subsection{Experimental Design and} Management: The $40 \quad(20$ males and 20 females) rabbits (weight: 1000 - 1100g) selected for the trial were weight balanced in 4 groups of 10 ( 5 males and 5 females) and assigned to four (4) dietary treatments: T0, T1, T2 and T3 containing $0,15,20$ and $25 \%$ of TDLM respectively. The treatments were blocked (sexes) in a completely randomised design and each rabbit served as an experimental unit for 9 weeks.

3.6 Ingredients and percentage composition of experimental diets: These diets contained iso-protein and iso-caloric levels plus boiled TDLM incorporated at $0 \%, 15,20$ and $25 \%$, corresponding to $\mathrm{T} 0, \mathrm{~T} 1, \mathrm{~T} 2, \mathrm{~T} 3$ and T4 respectively as in Table 1 .

Table 1: Ingredients and percentage compositions in experimental diets.

\begin{tabular}{|c|c|c|c|c|}
\hline Composition (\%) & T0 (0\%) & T1 (15\%) & T2 $(20 \%)$ & T3 (25\%) \\
\hline Maize (red) & 22.5 & 29.0 & 32.0 & 35.0 \\
\hline Wheat bran & 18.5 & 11.5 & 12.0 & 8.0 \\
\hline Rice pulp & 25.0 & 18.0 & 14.0 & 11.5 \\
\hline Boiled TDLM & 00 & 15.0 & 20.0 & 25.0 \\
\hline Cotton seed cake & 5.5 & 3.0 & 2.0 & 2.0 \\
\hline Soybeans meal & 6.0 & 4.0 & 3.5 & 2.0 \\
\hline Palm Kernel cake & 15.0 & 12.5 & 10.0 & 10.0 \\
\hline Fish meal & 3.0 & 2.0 & 1.5 & 1.5 \\
\hline Sea shells & 1.0 & 0.5 & 0.5 & 0.5 \\
\hline Palm oil & 3.0 & 4.0 & 4.0 & 4.0 \\
\hline Premix $0,5 \%$ & 0.5 & 0.5 & 0.5 & 0.5 \\
\hline Total & 100.0 & 100.0 & 100.0 & 100.0 \\
\hline \multicolumn{5}{|c|}{ Calculated chemical composition of rations } \\
\hline Crude Protein $(\%)$ & 16.37 & 16.28 & 16.22 & 16.29 \\
\hline M. E. (Kcal/kg) & 2429.37 & 2431.22 & 2409.80 & 2403.97 \\
\hline Crude Fibre (\%) & 11.27 & 11.95 & 11.83 & 12.16 \\
\hline Calcium $(\%)$ & 0.78 & 0.82 & 0.88 & 0.98 \\
\hline Phosphorus $(\%)$ & 0.53 & 0.42 & 0.41 & 0.37 \\
\hline Lysine $(\%)$ & 0.85 & 0.63 & 0.56 & 0.49 \\
\hline Methionine $(\%)$ & 0.35 & 0.28 & 0.25 & 0.23 \\
\hline Ratio ME/CP & 148.40 & 149.33 & 148.56 & 147.53 \\
\hline Ratio $\mathrm{Ca} / \mathrm{P}$ & 1.47 & 1.91 & 2.15 & 2.61 \\
\hline Price (FCFA/kg) & 173.25 & 160.55 & 154.00 & 149.90 \\
\hline
\end{tabular}

*Composition of the premix: Vit A: 3,000.000IU, Vit D: 50,0000IU, Vit E: 6,000mg, Vit K: 600mg, Vit B1: 600mg, Vit B2: 800mg, Vit B3: 1800mg, Vit B6: 400mg, Vit12: 6mg, Folic acid: 250mg, Nacine: $600 \mathrm{mg}$, Cl

86,500mg, Fe: 12,000mg, Cu: 1200mg, Mn: 12,000mg, Zn: 10,000mg, I: 100mg, Se: 40mg, Mg: 3397mg, Na: 283mg, Ca: 215,166mg, Methionine: 130,000mg, Lysine: 50,000mg.

\subsection{Data collection}

3.7.1 Feed intake (g): Following one week of adaptation and feed of control diet to all treatments, the formulated diets (T0, T1, T2 and T3) were quantified and served to the rabbits on daily bases. Left overs were collected and weighed every morning before serving feed to the rabbits. Weekly feed intake was calculated by subtracting the left-over from that of the quantity served to each rabbit in each treatment. The average daily feed intake (DFI) was calculated by dividing the total weekly feed intake by seven.

DFI (g) = Quantity of Feed Served/day Left over Feed/day 
3.7.2 Evaluation of weight gain (g): At the start of the trial, all the rabbits in each treatment were weighed. Subsequently, they were weighed individually before feeding every seventh day, using an electronic balance with a precision of $1 \mathrm{~g}$. From this, the weekly weight gain (WG) was calculated by using the following formula

$\mathrm{WG}(\mathrm{g})=\mathrm{W}_{\mathrm{n}}-\mathrm{W}_{\mathrm{n}-1}$

Where WG: is the weight gain, $\mathrm{W}_{\mathrm{n}}$ : weight at the end of the current week and $\mathrm{W}_{\mathrm{n}-1}$ : weight taken at the beginning of the previous week.

3.7.3 Feed Conversion Ratio (FCR) of rabbits as affected by graded levels of boiled TDLM: The weekly feed conversion ratio was calculated using the formula bellow.

$\mathrm{FCR}=\underline{\text { Total FI }(\mathrm{g})}$

$$
\text { Total WG (g) }
$$

3.7.4 Carcass characteristics : At the end of the experiment 8 ( 4 males and 4 female) rabbits per treatment were randomly selected, staved for 24 hours, stunned and slaughtered for carcass evaluation according to Eschborn, (1985).

\section{RESULTS}

4.1 Effects of inclusion levels of treated $T$. diversifolia leaf meal (TDLM) on the growth performance of rabbits: Effects of inclusion levels of treated $T$. diversifolia leaf meal (TDLM) on the growth performance of rabbits are summarised in Table 2. Feed consumption (FC), daily weight gain (DWG), feed conversion ratio (FCR), and final weight were the same in males rabbits, females rabbits
3.7.4.1 Carcass yield: Carcass yield was calculated as the ratio of the dressed carcass weight to the live weight (after fasting) and multiplied by hundred. Carcass Yield $(\mathrm{Y} \%)=$

Weight of carcass $\times 100$

Live weight

3.7.4.2 Relative Percentage weight of organs (\%): The relative percentage of organs (liver, kidneys, pancreas and heart) were calculated as the ratio of the weight of organ or part to the live body weight and computed as Percentage organs weight $(\%)=$ Weight of organs $\times 100$ Live weight of animal

3.8 Data analyses: Data collected were submitted to two ways Analysis of Variance (ANOVA) in a completely randomised design of four treatments with 10 replicates of 5 males and 5 females. Means were separated for significant differences $(\mathrm{p}<0.05)$ using Duncan's multiple range test (Steel and Torrie 1980). The analyses were conducted using SPSS ${ }^{c} 20.0$ for windows program.

and overall males and females $(\mathrm{P}>0.05)$ at all inclusion levels of treated TDLM. However, weight gain was slightly higher in the males than females at all inclusion levels of TDLM. Slightly lower feed intake, higher weight gain and the least feed conversion ratio (FCR) were obtained with treatment T3 (25\% TDLM) for both sexes. 
Table 2: Effects of inclusion levels of treated T. diversifolia leaf meal (TDLM) on the growth performance of rabbits

\begin{tabular}{|c|c|c|c|c|c|}
\hline \multirow{2}{*}{$\begin{array}{l}\text { Growth } \\
\text { performance }\end{array}$} & & \multicolumn{4}{|c|}{ Inclusion levels of TDLM } \\
\hline & Sex & T0 (0\%) & T1 (15\%) & T2 $(20 \%)$ & T3 $(25 \%)$ \\
\hline $\begin{array}{ll}\text { Daily } & \text { feed } \\
\text { intake }(g) & \end{array}$ & \begin{tabular}{l}
1 \\
0 \\
0 \\
+ \\
$\vdots 0$ \\
\multicolumn{1}{c}{+}
\end{tabular} & $\begin{array}{l}120.60 \pm 12.22^{\mathrm{a}} \\
125.97 \pm 14.42^{\mathrm{a}} \\
123.29 \pm 13.32^{\mathrm{a}}\end{array}$ & $\begin{array}{l}111.70 \pm 14.00^{\mathrm{a}} \\
110.50 \pm 23.31^{\mathrm{a}} \\
111.1 \pm 18.66^{\mathrm{a}}\end{array}$ & $\begin{array}{l}102.90 \pm 24.02^{\mathrm{a}} \\
125.00 \pm 18.51^{\mathrm{a}} \\
113.95 \pm 30.52^{\mathrm{a}}\end{array}$ & $\begin{array}{l}108.71 \pm 15.40^{\mathrm{a}} \\
109.57 \pm 21.75^{\mathrm{a}} \\
109.14 \pm 18.58^{\mathrm{a}}\end{array}$ \\
\hline $\begin{array}{l}\text { Daily weight } \\
\text { gain }(g)\end{array}$ & $\begin{array}{l}1 \\
0 \\
0 \\
+ \\
\hat{0} 0 \\
\end{array}$ & $\begin{array}{l}23.10 \pm 3.30^{\mathrm{a}} \\
22.13 \pm 4.99^{\mathrm{a}} \\
22.62 \pm 4.15^{\mathrm{a}} \\
\end{array}$ & $\begin{array}{l}22.06 \pm 2.88^{\mathrm{a}} \\
21.28 \pm 2.92^{\mathrm{a}} \\
21.67 \pm 2.90^{\mathrm{a}} \\
\end{array}$ & $\begin{array}{l}23.64 \pm 2.43^{\mathrm{a}} \\
22.26 \pm 0.49^{\mathrm{a}} \\
22.95 \pm 2.92^{\mathrm{a}} \\
\end{array}$ & $\begin{array}{l}25.26 \pm 1.94^{\mathrm{a}} \\
23.71 \pm 2.88^{\mathrm{a}} \\
24.49 \pm 2.41^{\mathrm{a}} \\
\end{array}$ \\
\hline $\begin{array}{l}\text { Feed } \\
\text { conversion } \\
\text { ratio } \\
\end{array}$ & $\begin{array}{l}1 \\
0 \\
0 \\
+ \\
\hat{0} 0 \\
\end{array}$ & $\begin{array}{l}5.22 \pm 1.05^{\mathrm{a}} \\
5.94 \pm 1.49^{\mathrm{a}} \\
5.58 \pm 1.29 \mathrm{a} \\
\end{array}$ & $\begin{array}{l}5.25 \pm 1.60^{\mathrm{a}} \\
5.16 \pm 0.55^{\mathrm{a}} \\
5.21 \pm 1.08^{\mathrm{a}}\end{array}$ & $\begin{array}{l}4.62 \pm 0.11^{\mathrm{a}} \\
5.61 \pm 0.79^{\mathrm{a}} \\
5.12 \pm 0.45^{\mathrm{a}}\end{array}$ & $\begin{array}{l}4.58 \pm 1.32^{\mathrm{a}} \\
4.63 \pm 0.88^{\mathrm{a}} \\
4.61 \pm 1.10^{\mathrm{a}}\end{array}$ \\
\hline $\begin{array}{ll}\text { Final } & \text { live } \\
\text { weight }(g) & \end{array}$ & $\begin{array}{l}1 \\
0 \\
0 \\
+ \\
\hat{0} 0\end{array}$ & $\begin{array}{l}2527.75 \pm 292.27^{\mathrm{aAB}} \\
2648.60 \pm 355.68^{\mathrm{aA}} \\
2588.18 \pm 323.98^{\mathrm{a}}\end{array}$ & $\begin{array}{l}2465.50 \pm 187.61^{\mathrm{aA}} \\
2598.40 \pm 93.96^{\mathrm{abA}} \\
2531.95 \pm 140.79^{\mathrm{ab}}\end{array}$ & $\begin{array}{l}2595.50 \pm 190.88^{\mathrm{aA}} \\
2654.40 \pm 89.60^{\mathrm{aA}} \\
2624.95 \pm 140.24^{\mathrm{a}}\end{array}$ & $\begin{array}{l}2687.75 \pm 129.17^{\mathrm{aAB}} \\
2717.60 \pm 156.74^{\mathrm{aA}} \\
2702.68 \pm 142.96^{\mathrm{a}}\end{array}$ \\
\hline
\end{tabular}

a, b, c: Means within a raw with different superscript differ significantly $(\mathrm{P}<0.05) ; \mathrm{A}, \mathrm{B}$ : Means between sexes with different superscript differ significantly $(\mathrm{P}<0.05)$. $\mathrm{T} 0=0 \%$ of treated $T$. diversifolia, $\mathrm{T} 1=15 \%, \mathrm{~T} 2=20 \%$ and $\mathrm{T} 3=25 \%$ of treated $T$. diversifolia

4.2 Effects of inclusion levels of treated TDLM on the carcass characteristics of rabbits: The effects of inclusion levels of treated TDLM on the carcass characteristics of rabbits are summarised in Table 3. At all inclusion levels of TDLM, slaughter weight (g), dressed weight $(\mathrm{g})$ and carcass yields as well as the head and skin were comparable between all treatments for the males, females and overall males and female rabbits $(P>0.05)$. However, carcass yields were slightly higher $(P<0.05)$ in males than the females at all inclusion levels of TDLM. However, abdominal fats significantly $(P<0.05)$ increased in female rabbits with the inclusion of TDLM while it was the reverse with male rabbits. Nevertheless, abdominal fats and skin weight were higher in females than males with the exception of abdominal fats in T0 which was the same for both sexes.

Table 3: Effects of inclusion levels of boiled, dried and milled TDLM on the carcass characteristics of rabbits.

\begin{tabular}{|c|c|c|c|c|c|}
\hline \multirow{2}{*}{$\begin{array}{l}\text { Carcass } \\
\text { characteristics }\end{array}$} & & \multicolumn{4}{|c|}{ Inclusion levels of TDLM } \\
\hline & Sex & T0 (0\%) & T1 (15\%) & T2 (20\%) & T3 $(25 \%)$ \\
\hline \multirow{3}{*}{$\begin{array}{l}\text { Slaughter } \\
\text { weight }(g)\end{array}$} & $\hat{\sigma}$ & $2447.25 \pm 259.46^{\mathrm{a}}$ & $2324.75 \pm 142.93^{\mathrm{b}}$ & $2537.25 \pm 201.32^{a}$ & $2590.75 \pm 165.12^{\mathrm{a}}$ \\
\hline & q & $2570.50 \pm 242.52^{\mathrm{a}}$ & $2499.25 \pm 102.29^{a}$ & $2583.75 \pm 108.48^{a}$ & $2551.00 \pm 237.27^{\mathrm{a}}$ \\
\hline & jo+ & $2508.88 \pm 250.99^{a}$ & $2412.00 \pm 122.61^{\mathrm{ab}}$ & $2578.50 \pm 154.90^{\mathrm{a}}$ & $2570.88 \pm 201.20^{\mathrm{a}}$ \\
\hline \multirow{3}{*}{$\begin{array}{l}\text { Dressed } \\
\text { weight (g) }\end{array}$} & $\hat{o}$ & $1315.00 \pm 165.24^{\mathrm{a}}$ & $1266.00 \pm 65.61^{\mathrm{a}}$ & $1355.75 \pm 80.04^{a}$ & $1374.50 \pm 111.62^{\mathrm{a}}$ \\
\hline & q & $1306.50 \pm 101.95^{\mathrm{a}}$ & $1257.75 \pm 89.91^{\mathrm{a}}$ & $1283.75 \pm 77.18^{\mathrm{ab}}$ & $1282.75 \pm 108.08^{\mathrm{ab}}$ \\
\hline & jo+ & $1310.75 \pm 133.60^{\mathrm{a}}$ & $1261.88 \pm 77.76^{a}$ & $1319.75 \pm 78.61^{\mathrm{a}}$ & $1328.63 \pm 109.85^{\mathrm{a}}$ \\
\hline \multirow{3}{*}{$\begin{array}{l}\text { Carcass yield } \\
(\%)\end{array}$} & $\hat{\sigma}$ & $53.67 \pm 1.63^{\mathrm{aA}}$ & $54.48 \pm 0.53^{\mathrm{aA}}$ & $53.51 \pm 1.28^{\mathrm{aA}}$ & $53.01 \pm 0.98^{\mathrm{aA}}$ \\
\hline & $q$ & $50.89 \pm 1.21^{\mathrm{aB}}$ & $50.29 \pm 2.21^{\mathrm{aB}}$ & $49.66 \pm 1.22^{\mathrm{aB}}$ & $50.33 \pm 1.93^{\mathrm{aB}}$ \\
\hline & $\hat{o}+9$ & $52.28 \pm 1.42^{\mathrm{a}}$ & $52.39 \pm 1.37^{\mathrm{a}}$ & $51.59 \pm 1.25^{\mathrm{a}}$ & $51.67 \pm 1.46^{\mathrm{a}}$ \\
\hline \multirow{3}{*}{$\begin{array}{l}\text { Abdominal fats } \\
(\%)\end{array}$} & $\bar{\sigma}$ & $2.14 \pm 0.51^{\mathrm{Aa}}$ & $1.96 \pm 0.82^{\mathrm{bB}}$ & $0.87 \pm 0.39^{\mathrm{bB}}$ & $1.41 \pm 0.64^{\mathrm{bB}}$ \\
\hline & q & $1.65 \pm 0.51^{\mathrm{bB}}$ & $2.32 \pm 0.58^{\mathrm{abA}}$ & $3.69 \pm 0.95^{\mathrm{aA}}$ & $2.75 \pm 1.87 \mathrm{abA}$ \\
\hline & $\delta^{\lambda}+t^{2}$ & $1.90 \pm 0.51^{\mathrm{ab}}$ & $2.14 \pm 0.07^{\mathrm{a}}$ & $2.28 \pm 0.67^{a}$ & $2.08 \pm 1.26^{\mathrm{a}}$ \\
\hline \multirow{3}{*}{$\begin{array}{l}\text { Relative weight } \\
\text { of the head }(\%)\end{array}$} & $\overline{0}$ & $7.82 \pm 0.32^{\mathrm{ab}}$ & $8.75 \pm 1.08^{a}$ & $7.57 \pm 0.66^{\mathrm{ab}}$ & $7.06 \pm 1.07 \mathrm{ab}$ \\
\hline & $q$ & $7.44 \pm 0.44^{\mathrm{a}}$ & $7.77 \pm 0.20^{\mathrm{a}}$ & $7.38 \pm 0.55^{\mathrm{a}}$ & $7.49 \pm 0.58^{a}$ \\
\hline & ô우 & $7.63 \pm 0.38^{a}$ & $8.26 \pm 0.64^{\mathrm{a}}$ & $7.48 \pm 0.61^{\mathrm{a}}$ & $7.28 \pm 0.83^{\mathrm{a}}$ \\
\hline \multirow{3}{*}{$\begin{array}{l}\text { Relative weight } \\
\text { of the skin }(\%)\end{array}$} & $\overline{0}$ & $8.78 \pm 1.20^{\mathrm{aB}}$ & $10.05 \pm 0.52^{\mathrm{aA}}$ & $9.76 \pm 1.49^{\mathrm{aB}}$ & $8.17 \pm 2.20^{\mathrm{aB}}$ \\
\hline & $q$ & $10.21 \pm 0.97 \mathrm{aA}$ & $10.77 \pm 1.09^{\mathrm{aA}}$ & $11.23 \pm 1.52^{\mathrm{aA}}$ & $11.06 \pm 1.35^{\mathrm{aA}}$ \\
\hline & tip & $9.50 \pm 2.17^{\mathrm{a}}$ & $10.41 \pm 0.81^{\mathrm{a}}$ & $10.50 \pm 1.51^{\mathrm{a}}$ & $9.62 \pm 1.78^{\mathrm{a}}$ \\
\hline
\end{tabular}

a, b, c: Means within a rows with different superscript differ significantly $(\mathrm{P}<0.05)$. A, B: Means within a column with different superscript differ significantly $(\mathrm{P}<0.05)$. $\mathrm{T} 0=0 \%$ of treated $T$. diversifolia, $\mathrm{T} 1=15 \%, \mathrm{~T} 2=20 \%$ and $\mathrm{T} 3=25 \%$ of treated $T$. diversifolia. 


\subsection{Effects of inclusion levels of treated} TDLM on the percentage weights of organs: The effects of inclusion levels of TDLM on the relative percentage weight of the lungs, liver, kidneys and hearts of rabbits are summarised in Table 4. Except for the relative weight of the lungs which decreased linearly in male rabbits and became significant in T3 (25\%
TDLM), the rest of the organs (liver, kidneys and heart) showed no significant differences $(p>0.05)$ in males, females and overall males and females. However, the relative percentage of the lungs was significantly higher $(p>0.05)$ in females than males except for T2 while the other treatments did not follow any pattern that could be attributed to the sexes.

Table 4: Effects of inclusion levels of boiled, dried and milled TDLM on the relative percentage weight of organs of rabbits

\begin{tabular}{|c|c|c|c|c|c|}
\hline \multirow{2}{*}{$\begin{array}{l}\text { Relative weight of } \\
\text { some organs }(\%)\end{array}$} & & \multicolumn{4}{|c|}{ Inclusion levels of TDLM } \\
\hline & Sex & T0 (0\%) & T1 (15\%) & T2 $(20 \%)$ & T3 (25\%) \\
\hline \multirow{3}{*}{$\begin{array}{l}\text { Relative weight of the } \\
\text { lungs }(\%)\end{array}$} & $\hat{0}$ & $0.46 \pm 0.07^{\mathrm{aB}}$ & $0.46 \pm 0.04^{\mathrm{aB}}$ & $0.42 \pm 0.05^{\mathrm{abA}}$ & $0.36 \pm 0.05^{\mathrm{bA}}$ \\
\hline & q & $0.59 \pm 0.20^{\mathrm{aA}}$ & $0.63 \pm 0.29^{\mathrm{aA}}$ & $0.35 \pm 0.12^{\mathrm{aA}}$ & $0.48 \pm 0.14^{\mathrm{aA}}$ \\
\hline & jo우 & $0.53 \pm 0.14^{\mathrm{a}}$ & $0.55 \pm 0.17^{\mathrm{a}}$ & $0.39 \pm 0.09^{\mathrm{a}}$ & $0.42 \pm 0.10^{\mathrm{a}}$ \\
\hline \multirow{3}{*}{$\begin{array}{l}\text { Relative weight of the } \\
\text { livers }(\%)\end{array}$} & $\hat{0}$ & $2.20 \pm 0.29 \mathrm{aA}$ & $2.29 \pm 0.07 \mathrm{aA}$ & $2.02 \pm 0.10^{\mathrm{aB}}$ & $1.94 \pm 0.44^{\mathrm{aB}}$ \\
\hline & q & $2.14 \pm 0.20^{\mathrm{aA}}$ & $2.20 \pm 0.14^{\mathrm{aA}}$ & $2.44 \pm 0.34^{\mathrm{aA}}$ & $2.38 \pm 0.21 \mathrm{aA}$ \\
\hline & jo+ & $2.17 \pm 0.25^{\mathrm{a}}$ & $2.25 \pm 0.11^{\mathrm{a}}$ & $2.23 \pm 0.22^{\mathrm{a}}$ & $2.16 \pm 0.33^{\mathrm{a}}$ \\
\hline \multirow{3}{*}{$\begin{array}{r}\text { Relative weight of the } \\
\text { kidneys }(\%)\end{array}$} & $\hat{0}$ & $0.59 \pm 0.11^{\mathrm{aA}}$ & $0.51 \pm 0.10^{\mathrm{aA}}$ & $0.47 \pm 0.11^{\mathrm{aB}}$ & $0.44 \pm 0.11^{\mathrm{aB}}$ \\
\hline & $q$ & $0.52 \pm 0.07 \mathrm{aB}$ & $0.45 \pm 0.03^{\mathrm{aB}}$ & $0.49 \pm 0.12^{\mathrm{aA}}$ & $0.49 \pm 0.06^{\mathrm{aA}}$ \\
\hline & 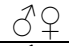 & $0.56 \pm 0.09^{\mathrm{a}}$ & $0.48 \pm 0.13^{\mathrm{a}}$ & $0.48 \pm 0.12^{\mathrm{a}}$ & $0.47 \pm 0.09^{\mathrm{a}}$ \\
\hline \multirow{3}{*}{$\begin{array}{l}\text { Relative weight of the } \\
\text { hearts }(\%)\end{array}$} & $\hat{0}$ & $0.20 \pm 0.06^{\mathrm{aA}}$ & $0.23 \pm 0.01^{\mathrm{aA}}$ & $0.20 \pm 0.05^{\mathrm{aB}}$ & $0.20 \pm 0.05^{\mathrm{aB}}$ \\
\hline & q & $0.21 \pm 0.02^{\mathrm{aA}}$ & $0.23 \pm 0.07^{\mathrm{aA}}$ & $0.29 \pm 0.07^{\mathrm{aA}}$ & $0.22 \pm 0.02^{\mathrm{aA}}$ \\
\hline & into & $0.21 \pm 0.04^{\mathrm{a}}$ & $0.23 \pm 0.04^{\mathrm{a}}$ & $0.25 \pm 0.06^{\mathrm{a}}$ & $0.21 \pm 0.04^{\mathrm{a}}$ \\
\hline Testes weight & $\sigma^{1}$ & $0.09 \pm 0.04^{c}$ & $0.18 \pm 0.07$ a & $0.15 \pm 0.05^{\mathrm{a}}$ & $0.12 \pm 0.04^{b}$ \\
\hline
\end{tabular}

a, b, c Means within a columns with different superscript differ significantly $(\mathrm{P}<0.05)$. T0 $=0 \%$ of treated $\mathrm{T}$. diversifolia, $\mathrm{T} 1=15 \%, \mathrm{~T} 2=20 \%$ and $\mathrm{T} 3=$ $25 \%$ of treated T. diversifolia.

\section{DISCUSSION}

In this study, the overall daily feed consumption decreased (123.29 - $109.14 \mathrm{~g} /$ day) with the inclusion of boiled dried and milled $T$. diversifolia leaf meal (TDLM) in the diets (Table 2) though, the decrease was not significant. Feed intake was slightly higher in females $(125.97$ - 109.57g) than males (120.60 $108.71 \mathrm{~g}$ ) with the highest values for both sexes observed in T0 (control). This finding agrees with Adedeji et al, (2012) and Foku, (2014), who reported a decrease in feed consumption when $T$. diversifolia leaves were incorporated into the diets of rabbits. This decrease was associated to low palatability of the diets resulting from the bitter taste of the leaves occasioned by the presence of anti-nutritional factors including tannins, alkaloids and sesquiterpene lactones as well as the bulk of the feed which tend to increase with the inclusion levels of TDLM in the diets. The daily feed intake in this study was higher than $89.53-97.75 \mathrm{~g} / \mathrm{d}$ reported by Foku,
(2014). The differences may also be linked to the levels of toxicity (anti-nutrients) in the leaves since some of the anti-nutrients must have been eliminated by boiling the leaves for 5 minutes. Foku, (2014) simply sundried T. diversifolia leaves and milled which implies that the toxicity level and bitterness was without any doubt higher and induced a decrease in feed intake in the male rabbits than the boiled leaves which had neither effect on males nor on female rabbits. Overall, daily weight gain varied from 21.67 - $24.49 \mathrm{~g} / \mathrm{d}$ and though, no significant differences were noted between treatments, it was higher in males (22.06 $25.26 \mathrm{~g} /$ day $)$ than in female (21.28 $23.71 \mathrm{~g} /$ day) rabbits. This findings were higher than 12.37 - 19.81g/d reported by Foku, (2014) in whose trial, daily weight gain was decreasing as $T$. diversifolia leaf meal was increasing in the diets. Daily feed intake and weight gain in both males and female rabbits at all inclusion levels 
of TDLM were similar to the control but higher than the values reported by Akinmutimi and Osuagwu (2008); Frederick Nahu (2010) and Adedeji et al., (2012). However, the daily weight gain, irrespective of sexes was comparable to Ogunsipe et al., (2014) when sorghum replaced maize up to $50 \%$ in the rations of rabbits. However, daily weight gain was lower than 24 $30 \mathrm{~g}$ reported by Okorie (2003) and Bhatt and Swain (2003). Overall feed conversion ratio varied from $4.61-5.58$; males $(4.63-5.94)$ and females (4.58 - 5.25), tending to decrease slightly in both sexes with the inclusion of TDLM in the diets, contrarily to the report of Foku, (2014) who used inclusion levels of simply sun-dried TDLM and obtained feed conversion ratio (FCR) from $5.92-9.27$. Foku (2014) noticed that FCR was increasing as the percentage of TDLM was increased in the diets which was not the case with boiled TDLM. This could be attributed to the presence of antinutrients like tannins and saponins which were fully present in the leaf meal. Nevertheless, FCR in the present study was similar to the control in all treatments but higher than those reported by Okorie, 2003; Eustace et al, 2003) and lower than the values reported by Jokthan et al, (2003) when rabbits were fed with fig (Ficus thonningii) and mango (Mangifera indica) leaves. The incorporation of graded levels of boiled, sun-dried and milled TDLM in the diets of rabbits had no significant ( $p>0.05)$ effect on the overall carcass characteristics of the rabbits at all inclusion levels. However, carcass yields were significantly $(\mathrm{p}<0.05)$ higher in males $(53.01-54.48 \%)$ than females $(49.66-50.89 \%)$ at all inclusion levels of TDLM. Carcass yields were lower when compared to $67.60-68.40 \%$ obtained by Uko et al, (2001) who used flame to remove fur from rabbit and the heads were left intact, contrary to this study, the rabbits were skinned and the heads were cut off. Overall carcass yields were 51.59 - 52.39\%. According to Njidda and Isidahomen (2010), dressing percentage of growing rabbits fed grasshopper meal ranged from 45.75 to $70.03 \%$. Foku, (2014) used graded levels of $T$. diversifolia leaf meal simply sun-dried and obtained carcass yields from $45-50$. In the present study, overall abdominal fat was (1.90 $2.28 \%)$; males $(0.87-2.14 \%)$ and females $(1.65$ - 3.69\%). In males, abdominal fats decreased with the inclusion of boiled TDLM while in female, it was the reverse. Moreover, abdominal fat was higher in females than in male rabbits. Foku, (2014) observed a decrease in total abdominal fats with the inclusion of simply sun-dried TDLM in the diets of male rabbits which also agrees with this study but contradicts with female rabbits. These differences were associated to the levels of antinutritional factors after processing (KreijkampKaspers et al, 2005). Diet is the most influential factor of fat deposit levels in animals and can greatly influence the development of atherosclerosis in the animals and consequently in the consumers of the meat. Nevertheless, atherosclerosis in rabbits is influenced by $4-8 \%$ fats by weight. If diet contains more than $1 \%$ cholesterol, rabbits will suffer from high hyper cholesterolemia and show massive lipid accumulation in some organs and in the abdomen which can also influence the relative weight of the heart. In this study, there were no significant differences in the overall weights of the hearts of rabbits between treatments. Nevertheless, slightly higher relative weights of the heart were observed in females (0.21 $0.29 \%)$ than in male $(0.20-0.23)$ rabbits which may be linked to the higher level of fats in females than males. The overall liver percentage did not show any significant differences but considering sexes, liver percentages increased lineally with increasing levels of TDLM in the diets whereas, the reverse was observed in male rabbits. Though no significant differences were observed in different treatments, there were differences observed between sexes. These differences may account for the fact that the residue of phytochemicals in the leaf meal 


\section{CONCLUSION}

Under the condition of this study to evaluate the dietary potentials of graded levels of boiled, drained, dried and milled $T$. diversifolia leaf meal (TDLM) on the growth performance and carcass characteristics of rabbits, boiled TDLM induced a decrease in feed intake, decreased feed conversion ratio and improved weight gain though, there were no significant differences observed at all inclusion levels. The same observation was seen in carcass yield and organ characteristics with no significant differences observed. $T$. diversifolia leaves boiled for 5 minutes, sundried and milled can therefore be used as an alternative ingredient which could be included in the rations of rabbits up to $25 \%$ and growth and carcass performance will still

\section{REFERENCES}

Adedeji O.S., Amao S.R., Ameen S.A., Olayeni T.B., Ojedapo L.O and Ayandiran T.A., (2012). The effects of graded levels of wild sunflower meal on growth and blood parameters in weaned rabbits. Continental Journal of Ani. and Vet; Research. 4(1): 22-26. ISSN: 2141 - 405X (http://www.wiloludjournal.com.)

NIGERIA.

Akinmutimi A. H., Osuagwu C. C., (2008). Response of weaner rabbits fed graded levels of sweet potato meal in place of maize-based diet. Pakistan J. Nutr., 7 (5): 705-709.

A.O.A.C. (1990). Official Methods of Analysis. Association of Official Analytical Chemists (15th ed.) Vol. 2 Associate of Official Chemistry, Arlington, Virginia, U.S.A.

Awono C., Laroche-Dupraz C., Grongnet J. F., Vermersch D., Havard M. et Lhuissier A., (2005). Déterminants de la consommation urbaine de poulet de chair au Cameroun: cas de la ville de Yaoundé. Agrocampus de Rennes, Département d'économie rurale et gestion, 65 rue de Saint-Brieuc, 35042 Rennes Cedex, France. 9 p. be comparable to rabbits placed on conventional ingredients irrespective of the sex. However, the use of TDLM could be more advantageous because it could significantly reduce the cost of feeding and enhance meat production due to its relative abundance in nature as compared to other ingredients. The inclusion of $25 \%$ of TDLM boiled at $100^{\circ} \mathrm{C}$ for 5 minutes is therefore recommended to rabbit farmers.

Perspectives: With the use of TDLM in the diets of rabbits, studies should be conducted on the evaluation of meat quality as well as studies should be carried out with the use of inclusion levels higher than $25 \%$.

Bhatt and Swain N., (2003). Effect of graded level of fat supplementation on the growth performance in the rabbits. World Rabbit Science, 11 (1): 33-40.

Effiong, O.O. and Wogar G.S. (2007). Litter performance traits of rabbits under mixed feeding regim. Proc. $32^{\text {nd }}$ Annual Conference of the Nigerian Society of Animal Production, Calaba, March 186 21, 2017 pp: 155 - 158

Ernest Nyanga Maragara (2000). An evaluation of $T$. diversifolia and Sapium ellipticum as supplement fodder for ruminants; MSc. Thesis, Dep. of Ani. Prod., Univ. of Nairobi. Library No. 05096508, 2009; p105.

Eustace A., Iyayi O., Oluwakemi $\mathrm{O}$ and Odueso M., (2003). Response of some metabolic and biochemical indices in rabbits fed varying levels of dietary cyanide. African Journal of Biomedical Research, 6(1):43-47.

FAO, (2005). Base de données statistiques FAOSTAT. Rome. www.faostat.fao.org

Fasuyi A.O., Dairo F.A.S. and Ibitayo F.J., (2010). Ensiling wild sunflower (Tithonia diversifolia) leaves with sugar cane molasses. Livestock Research for Rural 
Development volume 22, articles \#42. Retrieved December 7, 2010,

Foku. V. K., (2014). Growth performance, carcass characteristics, some haematological and bio-chemical parameters of male local rabbits fed graded levels of wild sun flower ( $T$. diversifolia Hemsl A. Gray) leave meal. Dep. of Animal Production. PP 42-62.

Frederick N., (2010). Effect of moringa leaf meal (MOLM) on nutrient digestibility, growth, carcass and blood indices of weaner rabbits page. Kwame Nkrumah University of Science and Technology, Kumasi, Ghana. 122p.

Jokthan, G.E., Alawa J.P., Adamu A.M. and Adeyinka I.A. (2003). The effect of different fibre sources on the performance of young rabbits. Proc. of the 28 Ann. Conf. of the Nig. Soc. Anim. Prod. (NSAP), Th pp: 375-377.

Khattab, R.Y. and S.D. Arntfield, (2009). Nutritional quality of legume seeds as affected by some physical treatments, Anti-nutritional factors. LWT - Food Sci. and Technology, 42: 1113-1118

Khokhar S., Chauhan B. M., (1997). Antinutritional factors in Moth Bean (Vigna aconitifolia): Varietal Differences and Effects of Methods of Domestic Processing and Cooking. Food Chem. Vol. 59(3): 367-371.

Kreijkamp-Kaspers S., Kok L., Bots M. L., Grobbee D. E. and Van Der Schouwy T. (2005). Dietary phytoestrogens and plasma lipids in Dutch postmenopausal women; a cross-sectional study. Atherosclerosis, 178: 95-100.

Mada, S.B., A. Garba, A. Mohammed, A. Muhammad, A. Olagunju, H. A. Mohammed, (2012). Effects of Boiling and Roasting on Antinutrients and Proximate Composition of Local and Some Selected Improved Varieties of Arachis hypogaea L. International Journal of Food Nutrition and Safety, 1 (1): 45-53, ISSN: 2165-896X
Mahecha L. and Rosales M., (2005). Valor nutricional del follaje de Botón de oro Tithoniq diversifolia (Hemsl.) Gray, en la producción animal en el trópico. Livestock Research for Rural Development Volume 17. Article \#100. Retrieved April, 2011.

Njidda A.A. and Isidahomen C.E., (2010). Haematology, blood chemistry and carcass characteristics of growing rabbits fed grasshopper meal as a substitute for fish meal. Pakistan Vet. J., 30(1): 7-12. K and R. Merck, (Ed). Soil Organic matter dynamics and sustainability. Trop. Agric., pp: 331-338.

Norton B.W. (1994). The nutritive value of tree legumes. In: Forage tree legumes in tropical agriculture. Edited by R.C. Gutteridge and H.M. Shelton. CAB International, Wallingford, Oxon. 177191.

Okorie K.C., (2003). The effect of palmitic acid fortified maize wet milling by-product on the performance of weaner rabbits. Czech. J. Anim Sci, 48(9): 365-370.

Onifade A.A. and Tawe O.O., (1993). Alternative tropical feed resources in the rabbit diet. Growth performance, diets digestibility and blood meal composition.World rabbit science 1(0: 217-224).

Pamo T.E., Boukila B., Fonteh F.A., Tendonkeng F. et Kana J.R., (2005). Composition chimique et effets de la supplémentation avec Calliandra calothyrsus et Leucaena leucocephala sur la production laitière et la croissance des chevreaux nains de Guinée. Livestock Research for Rural Development. Vol. 17. Art. \# 34. R etrieved from http://www.cipav.org.co/Irrd17/03/te do17034.htm. 05/06/2011.

Pathoummalangsy K. and Preston T.R., (2008). Effects of supplementation with rumen fermentable carbohydrate and sources of 'bypass' protein on feed intake, digestibility and $\mathrm{N}$ retention in growing 
goats fed a basal diet of foliage of Tithonia diversifolia. Livestock Research for Rural Development. Volume 20, supplement. Retrieved July 9, 2010, from

http://www.lrrd.org/lrrd20/supplemen t/kham20076.htm.

Sallau, A. B., S. B. Mada, Ibrahim S., U. Ibrahim, (2012). Effect of Boiling, Simmering and Blanching on the Antinutritional Content of Moringa oleifera Leaves. International Journal of Food Nutrition and Safety, 2012, 2(1): 1-6,

Steel R.G. and Torrie J.H., (1980). Principles and procedures of statistics. McGraws Hill Book C, New York 633 pp.

Uko O., Ataja and Tanko H.B., (2001). Cereal by products as alternative energy sources in diets for rabbits: growth performance, nutrient digestibility and carcass yield. Trop Anim Prod Invest, 4: 67-76.

Wambui C.C, Abdulrazak S.A, Noordin Q. (2006). The effect of supplementing urea treated maize stover with tithonia, calliandra and sesbania to growing goats. Livest. Res. Rural Dev., 18 (5):64. 